\title{
Brain Superoxide Anion Generation in Asphyxiated Piglets and the Effect of Indomethacin at Therapeutic Dose
}

\author{
MASSROOR POURCYROUS, CHARLES W. LEFFLER, HENRIETTA S. BADA,
} SHELDON B. KORONES, AND DAVID W. BUSIJA'

\begin{abstract}
Laboratory' for Research in Neonatal Physiology', Brain Injury Research Center, Departments of Pediatrics [M.P., C.H.L., H.S.B., S.B.K.], Obstetrics and Gynecology /H.S.B., S.B.K.], Physiology and Biophysics [M.P., C.W.L., D.H.B.J, The University of Tennessee, Memphis. Memphis. Tennessee 38163
\end{abstract}

\begin{abstract}
We have previously shown that generation of superoxide anion occurs in cerebral cortex during asphyxia/reventilation in newborn pigs and that a high dose of indomethacin $(5 \mathrm{mg} / \mathrm{kg}$ i.v.) abolishes superoxide anion production. The purposes of this study were 1 ) to determine whether the generation of superoxide anion occurs primarily during asphyxia or whether reventilation must take place, 2) to investigate the effects of indomethacin pretreatment at a therapeutic dose of $0.2 \mathrm{mg} / \mathrm{kg}$ i.v. on superoxide anion generation, and 3 ) to investigate the effects of oxypurinol, an oxygen free radical scavenger, on superoxide anion production during asphyxia/reventilation. Superoxide anion production on cerebral cortex was determined by superoxide dismutase-inhibitable nitroblue tetrazolium (NBT) reduction using closed cranial windows. Superoxide anion generation during asphyxia without reventilation was $4 \pm 2 \mathrm{pmol} \mathrm{NBT} / \mathrm{mm}^{2}$ per $20 \mathrm{~min}$, which was significantly lower than during asphyxia/reventilation (16 $\pm 4 \mathrm{pmol}$ $\mathrm{NBT} / \mathrm{mm}^{2}$ per $20 \mathrm{~min}$ ) but comparable to the control group ( $3 \pm 1 \mathrm{pmol} \mathrm{NBT} / \mathrm{mm}^{2}$ per $20 \mathrm{~min}$ ). Indomethacin given at therapeutic dosage before asphyxia/reventilation decreased superoxide anion production to $3 \pm 1 \mathrm{pmol}$ NBT/ $\mathrm{mm}^{2}$ per $20 \mathrm{~min}$, values not significantly different from the control group and from piglets pretreated with oxypurinol at a dose of $50 \mathrm{mg} / \mathrm{kg}$ i.v. $\left(4 \pm 2 \mathrm{pmol} \mathrm{NBT} / \mathrm{mm}^{2}\right.$ per 20 min). We conclude that in newborn pigs $l$ ) superoxide anions are generated largely during reventilation rather than during asphyxia; 2) the therapeutic dose of indomethacin $(0.2 \mathrm{mg} / \mathrm{kg})$ is effective in inhibiting the superoxide anion generation during asphyxia/reventilation; and 3) oxypurinol reduces the superoxide anion accumulation on cerebral cortex during asphyxia/reventilation. (Pediatr Res 34: 366-369, 1993)
\end{abstract}

\section{Abbreviations}

NBT, nitroblue tetrazolium

SOD, superoxide dismutase

IVH, intraventricular hemorrhage

aCSF, artificial cerebrospinal fluid

Received November 10, 1992; accepted April 26, 1993

Correspondence: Massroor Pourcyrous, M.D., Newborn Center, 853 Jefferson Ave., Room 201, Memphis, TN 38163.

Supported in part by grants-in-aid from the American Heart Association Tennessee Affiliate, the National Institute of Health, the Obstetrics \& Gynecology Special Education Fund, and the LeBonheur Children's Medical Center Small Grant.

' Current address: Department of Physiology and Pharmacology, Bowman Gray School of Medicine, Wake Forest University, Winston-Salem, NC 27103.
Oxygen free radicals are generated on cerebral cortex during asphyxia/reventilation (1), ischemia/reperfusion (2), seizures (3), concussive brain injury (4), and acute hypertension (5). Free radicals could be involved in cerebrovascular alterations by its effects on cerebral vascular tone and reactivity $(6,7)$ and on changes in the permeability of the blood-brain barrier (8). Oxygen free radicals are largely produced by the cerebral cortex via the prostaglandin $\mathrm{H}$ synthase pathway, and their production could be inhibited by administration of indomethacin (1-3), a cyclooxygenase inhibitor, administered at a high dose of $5 \mathrm{mg} / \mathrm{kg}$ i.v. Another potential source of superoxide anion production is the xanthine oxidase pathway (9). However, the concentration of xanthine oxidase in brain is thought to be low compared with other tissues $(10,11)$. Xanthine oxidase is inhibited by allopurinol and its potent metabolites oxypurinol, which are also both free radical scavengers (10).

Premature and full-term infants may experience asphyxic insults in the perinatal period, resulting in the generation of oxygen free radicals (1). Oxygen free radicals may contribute to postischemic brain edema (12) and complications of IVH (13). Because of the deficiency in endogenous oxygen free radical scavengers in premature babies (14), their ability to inactivate potentially toxic radicals is less efficient compared with older individuals. A large number of premature babies develop symptomatic patent ductus arteriosus, and for ductal closure infants are frequently given indomethacin at a dose of $0.2 \mathrm{mg} / \mathrm{kg}$ i.v. (15). It is not known whether this small dosage of indomethacin would be sufficient to inhibit superoxide anion production on the brain surface that is generated largely via metabolism of arachidonic acid via prostaglandin $\mathrm{H}$ synthase.

We hypothesize that in newborn pigs 1 ) oxygen free radicals are produced largely during reventilation and not during the period of asphyxia; 2) indomethacin at therapeutic dosage decreases oxygen free radical generation during asphyxia/reventilation; and 3) oxypurinol pretreatment prevents the superoxide anion accumulation on cerebral cortex during asphyxia/ reventilation.

\section{MATERIALS AND METHODS}

This protocol was reviewed and approved by the Animal Care and Use Committee of the University of Tennessee, Memphis. A total of 43 newborn pigs (weight, 680 to $2000 \mathrm{~g}$ ) of either sex, 1 to $5 \mathrm{~d}$ of age, were anesthetized with ketamine hydrochloride $(33 \mathrm{mg} / \mathrm{kg}$ i.m.) and acepromazine ( $3.3 \mathrm{mg} / \mathrm{kg}$ intramuscularly). Anesthesia was maintained with $\alpha$-chloralose $(50 \mathrm{mg} / \mathrm{kg}$ i.v. initially and then $10 \mathrm{mg} / \mathrm{kg} / \mathrm{h}$ i.v.). A catheter was inserted into the femoral artery to record the blood pressure and to draw blood samples. The animals were ventilated with room air using a piston-type ventilator (Harvard Apparatus Co., Inc., South Na- 
tick, MA). Temperature was maintained at 37 to $38^{\circ} \mathrm{C}$ by using a water-circulating heating pad.

Closed cranial windows as described previously $(1-3)$ were implanted over each parietal cortex. The window made of a stainless steel ring with a premounted glass coverslip was cemented in place with dental acrylic. Three needles pierced the ring to allow injection of $\mathrm{aCSF}$ and NBT/SOD under the window and flushing of the brain surface with aCSF. The space under the window was filled with aCSF $\left[\mathrm{Na}^{+} 150 \mathrm{mmol} / \mathrm{L}, \mathrm{K}^{+} 3 \mathrm{mmol} /\right.$ L. $\mathrm{Ca}^{2+} 1.25 \mathrm{mmol} / \mathrm{L}, \mathrm{Mg}^{2+} 0.6 \mathrm{mmol} / \mathrm{L}, \mathrm{Cl}^{-} 132 \mathrm{mmol} / \mathrm{L}$, glucose $3.7 \mathrm{mM}$, urea $6 \mathrm{mM}, \mathrm{HCO}_{3}{ }^{-2} 25 \mathrm{mmol} / \mathrm{L}$; $\mathrm{pH} 7.33, \mathrm{PCO}_{2}$ $\left.6.1 \mathrm{kPa}(46 \mathrm{~mm} \mathrm{Hg}), \mathrm{PO}_{2} 5.7 \mathrm{kPa}(43 \mathrm{~mm} \mathrm{Hg})\right]$. The volume directly below the window was approximately $0.5 \mathrm{~mL}$. Data on control and asphyxia/reventilation groups have been published previously (1) although all of these experiments were performed during the same period.

Experimental design. After placement of dual cranial windows, 20 to $30 \mathrm{~min}$ were allowed for stabilization. Each animal received pancuronium bromide, $0.1 \mathrm{mg} / \mathrm{kg}$ i.v. to prevent resistance against the respirator. In this study, 43 piglets were assigned into five groups: control $(n=7)$, asphyxia without reventilation $(n=$ $9)$, asphyxia with reventilation $(n=11)$, indomethacin treatment before asphyxia/reventilation $(n=4)$, and oxypurinol treatment before asphyxia/reventilation $(n=10)$. Indomethacin and oxypurinol both cross the blood-brain barrier $(16,17)$. To measure SOD-inhibitable NBT reduction in all groups (NBT, Sigma Chemical Co., St. Louis, MO), $2.4 \mathrm{mM}$ dissolved in aCSF was placed under one window and NBT $(2.4 \mathrm{mM})$ plus SOD (Sigma Chemical Co. $)(60 \mathrm{U} / \mathrm{mL})$ under the other window at the beginning of each experiment in the control animals and before asphyxia in the other animals.

The control animals were ventilated with room air for $20 \mathrm{~min}$. The asphyxia without reventilation group had $20 \mathrm{~min}$ of asphyxia induced by turning off the ventilator and occluding the endotracheal tube; no attempt was made to resuscitate the piglets. In asphyxia with reventilation group, asphyxia was induced for 5 to $7 \mathrm{~min}$ and ventilation was resumed when the animal exhibited severe bradycardia (heart rate $\leq 20$ beats/min) and/or when blood pressure decreased to $\leq 20 \mathrm{~mm} \mathrm{Hg}$. In the other two groups, $30 \mathrm{~min}$ before asphyxia/reventilation, either indomethacin trihydrate (gift from Merck Sharp \& Dohme Research Laboratory, Rahway, NJ) $0.2 \mathrm{mg} / \mathrm{kg}(n=4)$ or oxypurinol (Sigma Chemical Co.) $50 \mathrm{mg} / \mathrm{kg}(n=10)$ was given i.v. At the end of asphyxia in the asphyxia/reventilation group, blood samples were taken for blood gases and $\mathrm{pH}$ analysis and then animals were reventilated with room air. At the end of $20 \mathrm{~min}$ of experiments (from the start of asphyxia through reventilation), the brain surface was flushed with aCSF. The total time the NBT/SOD solutions were under the windows was the same for all 43 animals regardless of the treatment methods. At the end of experiment, the animals were killed by i.v. injection of $\mathrm{KCl}$ and bled. The cortex under each window was circumscribed using a $15-\mathrm{mm}$ diameter cork borer, and the circular area was sliced to a depth of approximately $1 \mathrm{~mm}$ using a sharp blade and then frozen for later analysis. The surface area under each window was $178 \mathrm{~mm}^{2}$, which was exactly the same in all samples.

NBT is a yellow, water-soluble compound that, in the presence of reducing agents, is converted to formazan, an insoluble purple precipitate. Although NBT can be reduced by various agents, SOD provides specificity for the assay. The SOD-inhibitable NBT reduction is determined by the difference in the quantities of formazan precipitated on the brain surface under the two windows. The purple precipitate always is located under each cranial window and does not extend beyond the border of the window. Consequently, there does not appear to be significant intermixing between windows of fluids injected into the windows. Kontos (18) has shown minimal intermixing of NBT solutions between windows in cats. By comparing the results from the two windows, we measured NBT reduction caused by superoxide anion radicals because superoxide anion radicals are dismutated in the presence of SOD.

Formazan was extracted from the brain slices into pyridine using the following method. The brain slices were minced, homogenized, and disrupted in a mixture of $0.1 \mathrm{~N} \mathrm{NaOH}$ and $0.1 \%$ SDS in water. The volume was then increased to $3 \mathrm{~mL}$ with water, the mixture centrifuged at $20000 \times g$ for $20 \mathrm{~min}$ to separate the water-soluble $\mathrm{Hb}$ from the formazan, and the resultant pellet was resuspended in $3 \mathrm{~mL}$ of pyridine. The formazan was dissolved in the pyridine during heating at $80^{\circ} \mathrm{C}$ for $1 \mathrm{~h}$. A second centrifugation $(10000 \times g$ for $10 \mathrm{~min})$ removed any remaining particulate matter. The concentration of formazan in the resultant solution was determined (against a standard curve) spectrophotometrically at $515 \mathrm{~nm}$. Formazan for use in the standards was prepared freshly by reducing NBT dissolved in $\operatorname{aCSF}(0.2 \mathrm{mg} / \mathrm{mL})$ with ascorbate $(1 \mathrm{mg} / \mathrm{mL})$. The standard then was handled identically and simultaneously with the samples and diluted in pyridine to produce concentrations from 100 $\mathrm{ng} / \mathrm{mL}$ to $2 \mathrm{mg} / \mathrm{mL}$. The concentration of formazan against the light absorption is linear over this range. Values are presented as $\mathrm{pmol} \mathrm{NBT}$ reduced $/ \mathrm{mm}^{2}$ in $20 \mathrm{~min}$.

Statistical analysis. All values are presented as means \pm SEM. Comparisons between two groups were made using $t$ tests for planned comparisons (paired or unpaired, as appropriate). Comparisons among more than two populations used analysis of variance followed by $t$ tests with Bonferroni correction. A $p$ value $<0.05$ was considered significant.

Results. All groups of piglets started with comparable values of arterial blood pressure, $\mathrm{pH}$, and gases (Table 1). Table 1 also shows the values of arterial blood pressure, $\mathrm{pH}$, and gases at the end of asphyxia immediately before reventilation; in the group with asphyxia without reventilation, arterial blood was sampled when there were no detectable heart rate and blood pressure. The piglets subjected to asphyxia without reventilation had no measurable heart rate or blood pressure in 12 to $15 \mathrm{~min}$ of asphyxia.

SOD-inhibitable NBT reduction was significantly increased in piglets that were exposed to asphyxia/reventilation when compared with the control group ( $16 \pm 4$ versus $3 \pm 1$ pmol NBT/ $\mathrm{mm}^{2}$ per 20 min. Fig. 1). Figure 1 shows the mean \pm SEM of SOD-inhibitable NBT reduction in the control group, asphyxia/ reventilation, asphyxia/no reventilation, indomethacin pretreated and oxypurinol pretreated groups (before asphyxia/reventilation). Piglets that were asphyxiated but not resuscitated had SOD-inhibitable NBT reduction of $4 \pm 2 \mathrm{pmol} \mathrm{NBT} / \mathrm{mm}^{2}$ per $20 \mathrm{~min}$, similar to control animals. Treatment of piglets with indomethacin at a dosage of $0.2 \mathrm{mg} / \mathrm{kg}$ i.v. or oxypurinol $50 \mathrm{mg} /$ $\mathrm{kg}$ i.v. before asphyxia/reventilation decreased the superoxide anion radical production to $3 \pm 3$ and $4 \pm 2 \mathrm{pmol} \mathrm{NBT} / \mathrm{mm}^{2}$ per $20 \mathrm{~min}$, respectively; values were comparable with control.

\section{DISCUSSION}

Based on our findings in newborn pigs, superoxide anions are generated on the brain surface largely during reventilation after asphyxia rather than during asphyxia; generation of superoxide anion is inhibited by pretreatment with a therapeutic dose of indomethacin; and oxypurinol reduced the superoxide anion accumulation on cerebral cortex during asphyxia/reventilation.

Oxygen free radicals are known to be generated in the brain. kidneys, heart, lungs, intestines (18-20), and other organ systems during a variety of insults. Superoxide anion is produced on the cerebral cortex during asphyxia/reventilation (1), ischemia/reperfusion (2), seizures (3), concussive brain injury (4), and acute hypertension (5). Oxygen free radicals are toxic to cells $(18,21)$ and can be involved in loss of cerebrovascular reactivity $(6,7)$ in the development of cerebral edema after recovery from ischemia (12) and in postasphyxic hypoperfusion $(22,23)$. During asphyxia/reventilation the SOD-inhibitable NBT reduction was significantly increased to $16 \mathrm{pmol} \mathrm{NBT} / \mathrm{mm}^{2}$ per $20 \mathrm{~min}$. Gen- 
Table 1. Arterial blood pressure, $p H$, and gas values for piglets*

\begin{tabular}{|c|c|c|c|c|c|c|c|c|}
\hline & \multicolumn{4}{|c|}{ Before asphyxia } & \multicolumn{4}{|c|}{ End of asphyxia } \\
\hline & $\begin{array}{l}\text { Arterial blood } \\
\text { pressure }(\mathrm{kPa})\end{array}$ & Arterial $\mathrm{pH}$ & $\begin{array}{l}\mathrm{PaCO}_{2} \\
(\mathrm{kPa})\end{array}$ & $\begin{array}{l}\mathrm{PaO}_{2} \\
(\mathrm{kPa}) \\
\end{array}$ & $\begin{array}{l}\text { Arterial blood } \\
\text { pressure }(\mathrm{kPa})\end{array}$ & Arterial pH & $\begin{array}{l}\mathrm{PaCO}_{2} \\
(\mathrm{kPa})\end{array}$ & $\begin{array}{l}\mathrm{PaO}_{2} \\
\text { (kPa) }\end{array}$ \\
\hline Control & $8.7 \pm 0.3$ & $7.41 \pm 0.06$ & $4 \pm 0.1$ & $11 \pm 0.5$ & & & & \\
\hline Asphyxia without reventilation & $9.9 \pm 0.8$ & $7.45 \pm 0.05$ & $4 \pm 0.1$ & $11 \pm 0.7$ & 0 & $7.01 \pm 0.07$ & $9 \pm 0.7$ & $0.7 \pm 0.3$ \\
\hline Asphyxia with reventilation & $8.1 \pm 0.4$ & $7.54 \pm 0.04$ & $4 \pm 0.1$ & $11 \pm 0.5$ & $2.7 \pm 0.4$ & $7.25 \pm 0.05$ & $7 \pm 0.4$ & $1.0 \pm 0.2$ \\
\hline $\begin{array}{l}\text { Indomethacin/asphyxia with } \\
\text { reventilation }\end{array}$ & $10.7 \pm 0.3$ & $7.42 \pm 0.04$ & $5 \pm 0.4$ & $9 \pm 0.9$ & $2.0 \pm 0.3$ & $7.15 \pm 0.04$ & $10 \pm 1.0$ & $0.4 \pm 0.06$ \\
\hline $\begin{array}{l}\text { Oxypurinol/asphyxia with re- } \\
\text { ventilation }\end{array}$ & $9.5 \pm 0.4$ & $7.38 \pm 0.01$ & $4 \pm 0.1$ & $10 \pm 0.7$ & $1.9 \pm 0.4$ & $7.05 \pm 0.06$ & $8 \pm 0.5$ & $0.5 \pm 0.1$ \\
\hline
\end{tabular}

*Values are mean $\pm \mathrm{SEM}$. Conversion factor: $\mathrm{mm} \mathrm{Hg}=\mathrm{kPa} / 0.1333$. $\mathrm{PaCO}_{2}$, partial pressure of arterial carbon dioxide; PaO ${ }_{2}$, partial pressure of arterial oxygen.

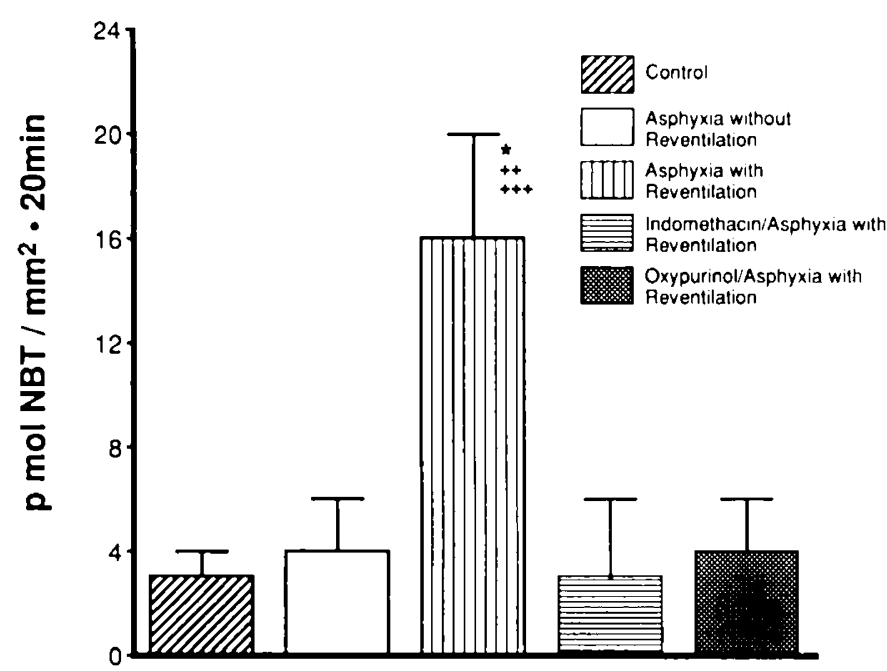

Fig. 1. SOD-inhibitable NBT reduction in control $(n=7)$, asphyxia without reventilation $(n=9)$, asphyxia/reventilation $(n=11)$, asphyxia/ reventilation after indomethacin $0.2 \mathrm{mg} / \mathrm{kg}(n=4)$, and asphyxia/ reventilation after oxypurinol $50.0 \mathrm{mg} / \mathrm{kg}(n=10)$ pretreated piglets. Values are mean \pm SEM. ${ }^{*}, p<0.05$ compared with control; ${ }^{++}, p<$ 0.05 compared with asphyxia without reventilation group: ${ }^{+++}, p<0.05$ compared with indomethacin and oxypurinol pretreatment groups.

eration of a similar quantity of superoxide on the cerebral surface from topical xanthine oxidase and hypoxanthine produced ultrastructural changes in pial microvessel endothelium (24).

Neonates are at high risk for hypoxic-ischemic insults. Many investigators have linked sequelae of these insults with the production of oxygen free radicals $(1,2,22)$. Thiringer et al. (23) reported that treatment of asphyxiated newborn lambs with oxygen free radical scavenger limited loss of somatosensory evoked potentials and preserved increased postasphyxia cerebral blood flow for a longer period. Rosenberg et al. (22) found that administration of SOD and catalase prevented postasphyxia hypoperfusion in lambs. Palmer et al. (12) reported a decrease in postischemic brain swelling after treating rat pups with allopurinol.

Superoxide anion production by the cerebral cortex in our piglets during asphyxia without reventilation was not significantly different from what was generated in control piglets. However, the level was much less than that produced during asphyxia with reventilation (1) and also during reperfusion after recovery from $20 \mathrm{~min}$ of global brain ischemia (2). Using the chemiluminescence method, Imaizumi et al. (25) observed free radical production in rat brain during early hypoxia. During early hypoxia and early reoxygenation, reactive hyperemia occurs (26) and more oxygen is available for oxygen free radical generation. The difference between our findings and those of Imaizumi et al. (25) may be attributable to a combination of severe hypoxia and hypotension in our experiments resulting in severe ischemia and probably insufficient cerebral oxygen for arachidonic acid metabolism before reventilation. The rats in the experiment of Imaizumi et al. (25) remained normocapnic and normotensive throughout the experiments thus presumably maintaining continual though reduced oxygen delivery. In contrast, our piglets were severely asphyxiated creating severe hypoxia and hypotension. This combination would result in very low oxygen delivery. Further, the additional severe acidosis and hypercapnia could possibly potentiate the free radical generation by lipid peroxidation if reperfusion were allowed (27).

Severe asphyxia or ischemic insult to the brain results in release of arachidonic acid (28). In early asphyxia, there is a reactive hyperemia $(22,26)$ that increases cerebral oxygen availability. During resuscitation, resurgence of blood flow and an increased oxygen availability allow the metabolism of accumulated arachidonic acid to prostanoids (29) and oxygen free radicals (1, 2). In piglets, superoxide anion generation in the brain caused by ischemia, seizures, and extravascular blood, as well as asphyxia/ reventilation, is prevented through administration of a high dose of indomethacin $(1-3,30)$. Because available evidence indicates that indomethacin lacks free radical scavenging properties, we believe that the effect of indomethacin on cerebral superoxide anion generation results from inhibition of cyclooxygenase activity. A free radical scavenger would eliminate superoxide anion radicals regardless of their source. Kontos et al. (31) observed absence of an effect of indomethacin on superoxide production by xanthine oxidase or activated polymorphonuclear cells. $\mathrm{Ku}$ kreja et al. (32) observed that indomethacin inhibited generation of oxygen free radicals via cyclooxygenase pathway but not through the lipooxygenase pathway. Also Mirro et al. (30) demonstrated that indomethacin decreased superoxide anion production by platelets but not the superoxide anion production by granulocytes, lymphocytes, and monocytes. Based on our present results, the therapeutic dose of indomethacin at $0.2 \mathrm{mg} / \mathrm{kg}$ appears as effective as the higher dose $(1-3)$ in preventing superoxide anion generation on the cerebral cortex during asphyxia/ reventilation.

Another possible route for oxygen free radical generation is via the xanthine oxidase pathway $(9,19)$. When the blood flow is decreased and there is insufficient oxygen available, depletion of ATP occurs and AMP accumulates that is later catabolized to adenosine, inosine, and hypoxanthine (33). With reperfusion and reoxygenation, xanthine oxidase catabolizes hypoxanthine to xanthine and xanthine to uric acid, with oxygen free radicals being generated in the process $(34,35)$. Oxypurinol is a major metabolite of allopurinol (36). Studies have shown that oxypurinol at the same molar concentrations as allopurinol could be up to 10 times as potent as allopurinol for eliminating superoxide production $(37,38)$. We observed attenuation of superoxide anion accumulation on cerebral cortex during asphyxia/reventilation when piglets were pretreated with oxypurinol; however, the mechanism of inhibition appears different from that of indomethacin because oxypurinol is not a prostaglandin $H$ synthase inhibitor. Although allopurinol and oxypurinol are both 
xanthine oxidase inhibitors (36), they are also oxygen free radical scavengers (10). Oxypurinol eliminates hydroxyl radicals that are not produced via xanthine oxidase pathway, and it also scavenges the myeloperoxidase-derived oxidant hypochlorous acid (10). Therefore, the inhibition of superoxide by oxypurinol can be explained by its scavenging effect, suggesting that indomethacin removes superoxide by inhibiting its production, whereas oxypurinol is equally effective by removing superoxide after it is produced.

Premature infants are at high risk for hypoxic-ischemic insults and for developing IVH (39). This risk is compounded by their low levels of endogenous free radical scavengers compared with term babies (14). In the clinical setting, the therapeutic dose of indomethacin is used widely for ductal closure and is beginning to be used for IVH prevention $(39,40)$. The attenuating effect on superoxide anion generation of this small dose of indomethacin may have future therapeutic implication in prevention of brain injury associated with IVH and hypoxic-ischemic episodes. Allopurinol or oxypurinol also could be an alternative drug in such research.

In summary, oxygen free radicals are produced largely during reventilation after asphyxia rather than during asphyxia per se; a therapeutic dose of indomethacin inhibits the superoxide anion production that occurs during recovery from asphyxia; and oxypurinol inhibits the superoxide radical accumulation during asphyxia/reventilation, probably by its direct scavenging effect.

Acknowledgment. The authors thank Alex Fedinec and John Pirani for their technical assistance.

\section{REFERENCES}

1. Pourcyrous M. Leffler CW, Mirro R. Busija DW 1990 Brain superoxide anion generation during asphyxia and reventilation in newborn pigs. Pediatr Res 28:618-621

2. Armstead WM, Mirro R, Busija DW, Lefller CW 1988 Postischemic generation of superoxide anion by newborn pig brain. Am J Physiol 255:H401-H403

3. Armstead WM. Mirro R. Lefller CW, Busija DW 1989 Cerebral superoxide anion generations during seizures in newborn pigs. J Cereb Blood Flow Metab 9:175-179

4. Wei EP. Dietrich WD. Povlishock JT, Navari RM. Kontos IIA 1989 Functional, morphological, and metabolic abnormalities of the cerebral microcirculation after concussive brain injury in cats. Circ Res 46:37-47

5. Kontos HA, Wei EP. Dietrich WD, Navari RM, Povlishock JT. Ghatak NR, Ellis EF. Patterson Jr JL 1981 Mechanism of cerebral arteriolar abnormalities after acute hypertension. Am J Physiol 240:H511-11527

6. Wei EP. Christman CW. Kontos HA. Povlishock JT 1985 Eflects of oxygen radicals on cerebral arterioles. Am J Physiol 248:H157-H162

7. Kontos HA. Wei EP. Povlishock JT, Christman CW 1984 Oxygen radicals mediate the cerebral anteriolar dilation from arachidonate and bradykinin in cats. Circulation 55:295-302

8. Wei EP, Ellison MD, Kontos HA, Povlishock JT $1986 \mathrm{O}_{2}$ radicals in arachidonate induced increased blood-brain barrier permeability to proteins. $\mathrm{Am}$ J Physiol 251:693-700

9. Thiringer K. Blomstrand S, Hrbek A, Karlson K. Kjellmer I 1982 Cerebral arteriovenous difference for hypoxanthine and lactate during graded asphyxia in the fetal lamb. Brain Res 239:107-117

10. Moorhouse PC. Grootveld M. Halliewell B. Quinlan G, Gutteridge JMC 1987 Allopurinol and oxypurinol are hydroxyl radical scavengers. FEBS Lett 213:23-28

11. Vettenranta K. Raivio KO 1990 Xanthine oxidase during human fetal development. Pediatr Res 27:286-288

12. Palmer C. Vannuccei RC. Towfighi J 1990 Reduction of perinatal hypoxicischemic brain damage with allopurinol. Pediatr Res 27:332-336

13. Ment LR, Stewart WB. Duncan CC 1985 Beagle puppy model of intraventricular hemorrhage: effect of superoxide dismutase on cerebral blood low and prostaglandins. J Neurosurg 62:563-569

14. Mishra OP. Delivoria-Papadopoulos M 1989 Antioxidant enzymes in fetal guinea pig brain during development and the effect of maternal hypoxia. Dev Brain Res 45:129-135

15. Friedman WF. Hirschklau MJ, Printz MP. Pitlick PT, Kirkpatric SE 1976 Pharmalogical closure of patent ductus arteriosus in the premature infant. N Engl J Mied 295:526-529

16. Kim P, Yaksh TL, Burnett PC, Blum MR. Sundt TM 1987 Cerebrospinal fluid levels of uric acid in dogs and the effect of allopurinol. Brain Res 402:87-92

17. Bannwarth B. Netter P, Lapicque F. Pere P. Thomas PH, Gaucher A 1990 Plasma and cerebrospinal tluid concentrations of indomethacin in humans. Eur J Clin Pharmacol 38:343-346

18. Kontos HA 1989 Oxygen radicals in cerebral vascular injury. Circ Res 57:508516

19. Granger DN, Hollwarth ME, Park DA 1986 Ischemia reperfusion injury: role of oxygen-derived free radicals. Acta Physiol Scand[Suppl]548:47-63

20. Ganduel Y. Duvellerory MA 1984 Role of oxygen radicals in cardiac injury due to reoxygenation. J Mol Cell Cardiol 16:459-470

21. Siesjo BK 1981 Cell damage in the brain: a speculative synthesis. J Cereb Blood Flow Metab 1:155-185

22. Rosenberg AA, Murdaugh E, White CW 1989 The role of oxygen free radicals in postasphyxial cerebra! hypoperfusion in newborn lambs. Pediatr Res 26:215-219

23. Thiringer K, Hrbek A. Karlsson K, Rosen KG, Kellman J 1987 Postasphyxic cerebral survival in newborn sheep after treatment with oxygen free radical scavengers and a calcium antagonist. Pediatr Res 22:62-66

24. Lefller CW, Busija DW, Armstead WM. Shanklin DR. Mirro R, Thelin O 1990 Activated oxygen and arachidonate effects on newborn cercbral arterioles. Am J Physiol 259:111230-111238

25. Imaizumi S, Kayman T. Suzuki J 1984 Chemiluminescence in hypoxic brain: the first report correlation between energy metabolism and free radical reaction. Stroke 15:1061-1065

26. Pourcyrous M, Letłler CW, Busija DW 1990 Role of prostanoids in cerebrovascular responses to asphyxia and reventilation in newborn pigs. $\mathrm{Am} \mathrm{J}$ Physiol 259:H662-H1667

27. Seisjo BK. Bendek G, Koide T, Westerberg E. Wieloch T 1985 Influence of acidosis on lipid peroxidation in brain tissue in vitro. J Cereb Blood Flow Metab 5:253-258

28. Yoshida S. Abe K. Busto R, Watson BD. Kogura K. Ginsherg MD 1982 Influence of transient ischemia on lipid-soluble antioxidants. free fatty acids, and energy metabolites in rat brain. Brain Res 245:307-316

29. Pourcyrous M. Lefller CW, Busija DW 1988 Postasphyxial increases in prostaglandins in cerebrospinal fluid in piglets. Pediatr Res 24:229-232

30. Mirro R. Armstead WM. Mirro J, Busija DW. Lefller CW 1989 Blood-induced superoxide anion generation on the cerebral conex of newborn pigs. Am J Physiol 257:111560-111564

31. Kontos HA. Wei EP. Ellis EF, Jenkins LW. Polishock JT. Rowe GT. Heas ML 1985 Appearance of superoxide anion radical in cerebral extracellular space during increased prostaglandin șnthesis in cats. Circ Res 57:142-151

32. Kukreja RC. Kontos 1 A. Hess ML, Ellis EF 1986 PGH synthase and lipoxygenase generate superoxide in the presence of NADM or NADPH. Circ Res 59:612-619

33. McCord JM 1985 Oxygen-derived free radicals in postischemic tissue injury $\mathrm{N}$ Engl J Med 312:159-163

34. Beckman JS, Marshall PA, Freeman BA 1987 Xanthine dehydrogenase to oxidase conversion in ischemic gerbil brain. Fed Proc 46:417-420

35. Patt A. Harken AH. Burton LK. Rodell TC. Piermattei D. Schorr WJ, Parker NB, Berger EM. Horesh IR, Terada LS, Linas SL. Cheronis JC, Repine JE 1988 Xanthine oxidase-derived hydrogen peroxide contributes to ischemia reperfusion-induced edema in gerbil brains. J Clin Invest 81:1556-1562

36. Gilman AG, Goodman LS, Rall TW. Murad FN (eds) 1985 Goodman \& Gilman's The Pharmacological Basis of Therapeutics, 7th Ed. Macmillan Publishing Co. New York. pp 710-712

37. Ko KM, Godin DV 1990 Inhibition of transition metal ion-catalysed ascorbate oxidation and lipid peroxidation by allopurinol and oxypurinol. Biochem Pharmacol 40:803-809

38. Zweier JL, Kuppusamy P. Lutty GA 1988 Measurement of enduthelial cell free radical generation: evidence for a central mechanism of free radical injury in postischemic tissues. Proc Natl Acad Sci USA 85:4046-4050

39. Bada HS. Green RS, Pourcyrous M. Lefller CW, Korones SB. Magill HL, Arheart K. Fitch CW, Anderson GD. Somes G. Tullis K. Campbell J 1989 Indomethacin reduces the risk of severe intraventricular hemorrhage. J Pediatr 115:631-637

40. Ment LR, Duncan CC, Ehrenkranz RA, Kleinman CS. Pitt BR, Taylor KJW, Scott DT, Stewart WB. Gettner P 1985 Randomized indomethacin trial for prevention of intraventricular hemorrhage in very low birth weight infants. J Pediatr 107:937-943 